\title{
DLACZEGO ZALEŻY NAM NA RZECZACH, KTÓRYCH NIE POTRZEBUJEMY? CZYLI MATERIALISTYCZNE UTOPIE W REALIACH PÓŹNEGO KAPITALIZMU
}

\section{ARTYKUŁ RECENZYJNY DOTYCZĄCY KSIĄŻKI \\ ANDRZEJA WAŚKIEWICZA LUDZIE - RZECZY - LUDZIE. \\ O PORZĄDKACH SPOŁECZNYCH, W KTÓRYCH RZECZY}

\section{ŁĄCZA, A NIE DZIELA}

Tomasz Maślanka

Uniwersytet Warszawski

Najnowsza publikacja Andrzeja Waśkiewicza, jak zresztą każda dobra książka, prowokuje czytelnika do postawienia sobie co najmniej kilku istotnych pytań, w tym wypadku odnoszących się przede wszystkim do przeobrażeń, kluczowych założeń oraz przyszłości systemu kapitalistycznego, opartego na nieustannym obiegu oraz konsumpcji przedmiotów materialnych, odgrywających w jego ramach przede wszystkim rolę dóbr pozycyjnych i statusowych. Nie jest to zatem, moim zdaniem, książka jedynie o utopiach, choć podejrzewam, że taki był właśnie zamysł jej autora - stworzenie szerokiej i erudycyjnej panoramy materialistycznych utopii. Jeśli się nie mylę co do istoty zamiaru Waśkiewicza, to efekt ten osiagnął on w swej książce z nawiązką. Należy uczciwie powiedzieć, że ów naddatek, o którym tu mowa, może rozczarować tych, którzy spodziewaliby się w tym miejscu „klasycznej recenzji”, w rodzaju drogowskazu czy wręcz przewodnika po 
bogactwie utopijnych idei, okraszonego tu i ówdzie, z recenzenckiej powinności, szczyptą kaśliwego komentarza czy mniej lub bardziej uzasadnioną krytyką. W eseju tym odnoszę się więc również do kilku kwestii, które expressis verbis nie pojawiają się jako bezpośredni efekt pracy historyka idei nad kompleksową materią całego przedsięwzięcia. Uważam, że taki jest hermeneutyczny przywilej każdego czytelnika. Taki jest także, według mnie, los wszystkich dobrych książek - zawsze wypowiadają więcej, niż chcą ich autorzy. Jeśli istnieje jakiś idealny typ odbiorcy podobnych recenzji, któremu potrzebny intelektualny bedeker i kompas do jego czytelniczych podróży, lepiej niech skończy lekturę na tym zdaniu. Dla pozostałych i tak zapewne nie ma to większego znaczenia i sami sięgna po książkę Waśkiewicza. Mogę jedynie dodać, że warto to zrobić, nawet jeśli nie jesteśmy pasjonatami materialistycznych utopii.

Rzeczy, można powiedzieć, zawsze były przedmiotem społecznej dystynkcji. W kulturze zachodniej celem gromadzenia przedmiotów było pierwotnie rozwijanie tożsamości posiadacza, ,ja” otoczonego przedmiotami jako parafernaliami wzniosłości i wysokiego statusu społecznego, co dobrze obrazuje portretowe malarstwo flamandzkie, ukazujące zasobnych mieszczan na tle zgromadzonych utensyliów.

W przeciwieństwie jednak do relacji interpersonalnych stosunek człowieka do rzeczy jest niejednoznaczny. Z jednej strony posiadanie rzeczy może być źródłem przyjemności, zwłaszcza jeśli relację tę cechuje poręczność w heideggerowskim znaczeniu tego terminu. $Z$ drugiej zaś świat przedmiotów materialnych może mieć dla człowieka alienujący charakter, pozbawiając go satysfakcji z posiadanych rzeczy, jeżeli funkcjonuja one wyłącznie jako wskaźniki statusu społecznego, czyli dobra pozycyjne, w których zawarty jest naddatek rywalizacyjny. Andrzej Waśkiewicz opisuje w swojej książce utopie, w których, jak wskazuje już tytuł publikacji, rzeczy łączą, a nie dzielą, czyli nie sa powodem dystynkcji i w konsekwencji nie prowadzą do alienacji. Wyróżnia on w wybranych przez siebie utopiach trzy motywy: racjonowanie, odtowarowienie i odwartościowanie. Sa to trzy idealne i ahistoryczne typy materialistycznych utopii, którym autor podporządkowuje wszystkie opisywane w pracy utopijne projekty, począwszy od starożytności, a na czasach najnowszych skończywszy. Wszystkie je łączy kwestionowanie konstytutywnych dla kapitalizmu zasad wymiany towarowo-pieniężnej jako sposobu organizacji relacji pomiędzy jednostkami.

W pierwszym przypadku chodzi o taki sposób reglamentowania zasobów, by nikt nie posiadał nadwyżki dóbr, odpowiadającej za powstawanie nierówności społecznych. Odtowarowienie oznacza nadanie rzeczom sta- 
tusu darów, będących przedmiotem dobrowolnej i bezpośredniej wymiany. Odwartościowanie natomiast, dzięki obfitości dostępnych zasobów, oznacza zaspokajanie potrzeb materialnych bez konieczności wikłania się w sieci relacji interpersonalnych. Autor zupełnie świadomie nie zastanawia się nad osiami podziałów ideologicznych, czyli najkrócej mówiąc, nie interesuje go, czy danej utopii bliżej do konserwatyzmu, libertarianizmu, czy socjalizmu. Modelowym niejako przykładem, pozwalającym na sproblematyzowanie rozproszonych treści poszczególnych, rozważanych w książce utopii, jest idea optimum dóbr, a zatem taka relacja człowiek-rzeczy, w której wszyscy mają to, czego potrzebują, a same rzeczy nie tworzą konfliktogennych hierarchii. Każda z omawianych w książce utopii ma takie optimum zapewnić. Idea optimum dóbr jest oczywiście, na co badacz zwraca uwagę, antykapitalistyczna, ponieważ podkopuje fundamentalne założenia i logikę działania systemu kapitalistycznego, którego funkcjonalnym imperatywem jest, jak wiadomo, maksymalizacja produkcji, stymulowana stale rosnąca konsumpcją. Występuje ona w rozmaitych konfiguracjach, w wielu wariantach krytyki kultury masowej i społeczeństwa konsumpcyjnego, zwłaszcza tych bardziej radykalnych, nawiązujących wprost lub pośrednio do dziedzictwa teorii krytycznej.

Sposób utopijnego myślenia o porządku społecznym, w którym rzeczy łączą ludzi, sprowadza się do wizji ładu eliminującego asymetryczność relacji społecznych, a przyczynę tej asymetrii utopiści widzą w nierównomiernej, resp. niewłaściwej, dystrybucji dóbr materialnych. Kolejnym motywem jednoczącym wybrane nurty utopijnego myślenia jest ich antykapitalistyczna orientacja, niekoniecznie w znaczeniu kwestionowania podstaw wymiany wolnorynkowej, ale na bardziej fundamentalnym poziomie - jako podważenie zasadności wymiany dóbr pomiędzy ludźmi, odpowiadającej za tworzenie więzi i relacji międzyludzkich.

Można więc powiedzieć, że utopijne projekty wyrastają tyleż z idealistycznych i często podszytych iluzjami predylekcji ich autorów do projektowania wyśnionych porządków społecznych, ile z krytyki zastanej rzeczywistości. Jakkolwiek zamysłem autora była, jak się zdaje, przede wszystkim analiza myślenia utopijnego, to książka, poruszając kwestie przenikania się złożonej infrastruktury świata materialnego i człowieczego, nieuchronnie wikła się jednak w szereg innych, istotnych dla przeobrażeń późnego kapitalizmu, problemów. Częściowo są one maskowane erudycją historyka, czasami gubią się pośród detalicznych i błyskotliwych opisów. Nie jest to oczywiście zarzut wobec książki, która nawet jeśli miała być jedynie rzetelnym studium $z$ historii utopijnych idei, to jednak zdecydowanie, moim 
zdaniem, wykroczyła poza ten horyzont. Czytając tę pozycję, odnosi się wrażenie, że jej twórca równie sprawnie porusza się po utopiach powstałych w Grecji czasów Platona co po tekstach całkiem współczesnych. Nie sposób rzecz jasna ustosunkować się do wszystkich omawianych w książce utopii, zwłaszcza jeżeli zamiarem recenzji nie jest jej streszczenie. Odniosę się więc jedynie do wybranych i moim zdaniem najbardziej interesujących kwestii.

Zacznijmy od tego, że w starożytnej Grecji różnice majątkowe stanowiły w zasadzie jedyną realna płaszczyznę stratyfikacji społecznej, jak powiedziałby socjolog. Platońska utopia, przy braku innych kryteriów zróżnicowania społecznego, jak choćby podziałów ideologicznych, bardziej współczesnych różnic wynikających ze stylu życia, etniczności czy konstruowanych tożsamości, skupia zatem jak w soczewce liczne intersujace problemy, odnoszące się wprost do relacji człowiek-rzeczy, różnic wynikających niemal jedynie ze zróżnicowania majątkowego. Wydaje się, że stosunek Platona i w ogólności starożytnych filozofów do posiadanego bogactwa, a co za tym idzie - do ludzi mogących sobie pozwolić na komfort niepodejmowania zajęć o charakterze zarobkowym, był co najmniej dwuznaczny. Z jednej strony ideał sprawiedliwego życia, które znaczyło dla starożytnych, mówiąc dzisiejszym językiem, harmonijne życie pod rządami rozumu, wymagał sporej ilości materialnego bogactwa, uwalniającego od przykrej konieczności pracy zarobkowej, zapewniającej środki do życia. Z drugiej strony bogactwo w sensie materialnym było dla Platona przeszkodą $\mathrm{w}$ prowadzeniu roztropnego vita contemplativa. Bogacenie się społeczeństwa, czyli wzrost gospodarczy, narusza bowiem dla Platona ład społeczny.

Elementy platońskiej utopii odnajdujemy również w egzemplarycznym dla gatunku dziele Thomasa Morusa. Utopia tego autora opiera się na kontrfaktycznym założeniu o niekonfliktogennym charakterze porządku społecznego, opartego na zróżnicowaniu funkcjonalnym. Każdy, kto zapoznał się z krótkim wywodem Kingsleya Davisa i Wilberta Moore’a o funkcjonalnej, a przez to nieuchronnej, genezie nierówności społecznych, zdaje sobie zapewne sprawę, że samo funkcjonalne zróżnicowanie pozycji społecznych, które u wymienionych autorów jest nieświadomie wypracowanym sposobem zapewnienia funkcjonalnie istotnych pozycji w społeczeństwie, nie wyklucza, a wręcz zakłada prestiż jako dodatkowy element podnoszenia lub obniżania statusu społecznego. Tam gdzie w grę wchodzi rywalizacja o prestiż, gdzie pojawiają się ambicje, tam tworzy się hierarchia i nie może być mowy o utopijnej harmonii. Nietrudno się 
domyślić, że takich kontrfaktycznych rozumowań w opisywanych przez Waśkiewicza utopiach odnajdziemy znacznie więcej. Dla Morusa najważniejsze było jednak zniesienie własności prywatnej i pieniędzy, czyli tego, co odpowiada za tworzenie podziałów i nierówności. W jego utopii mamy do czynienia z jawnym oskarżeniem ówczesnego skorumpowanego i opartego na nierównościach oraz niesprawiedliwych klasowych przywilejach społeczeństwa. Utopiści, jak zauważa Frederick Jameson (2011: 52), byli obsesjonatami i maniakami, nawet gdy sprawiali wrażenie zwyczajnych dostojników publicznych o zainteresowaniach literackich, jak Morus, lub ciekawych świata sybarytów, jak młody Henri de Saint-Simon.

Utopie, każda na swój sposób, próbują mierzyć się z dylematami społecznej sprawiedliwości. U Paula d'Holbacha na przykład dylemat ten przyjmuje postać fundamentalnego i wciąż aktualnego pytania, czy bogaci powinni wspomagać biednych. Odpowiedź na to pytanie ma u niego rys normatywny, ponieważ pomoc biednemu należy do obowiązków bogatego i jest jedynym słusznym użytkiem $z$ zasłużonego lub nie bogactwa. Taki normatywny wymiar rozważane kwestie uzyskały w bardziej współczesnych projektach, które trudno byłoby zaliczyć do utopii, jak choćby w teorii sprawiedliwości Johna Rawlsa. Sprawiedliwy porządek społeczny, opisany rzecz jasna w całkowicie innym, analitycznym języku normatywnych zasad sprawiedliwości, ostatecznie powinien kompensować deficyty oraz ułomności będące rezultatem upośledzeń, w które jednostki popadły bez własnej winy. Utopie nie powinny oczywiście zbliżać się za bardzo do reformatorskich projektów przebudowy życia codziennego, bo wówczas w większym stopniu przypominałyby polityczne projekty socjaldemokratycznej rekonstrukcji porządku społecznego niż utopijne pomysły radykalnej transformacji całego systemu, w które skądinąd obfitowały lata 60 .

$\mathrm{Z}$ mniej znanych utopii w recenzowanej książce pojawia się koncepcja Gospodarki Dobra Wspólnego Christiana Felbera, kładąca nacisk na problem niesymetrycznej akumulacji bogactwa, a nie jego sprawiedliwej redystrybucji. Natomiast z odniesień całkiem współczesnych znajdziemy przede wszystkim bardzo ciekawe uwagi o minimalizmie, ekonomii współdzielenia oraz koncepcję społeczeństwa zerowych kosztów krańcowych Jeremy'ego Rifkina.

Ekonomia współdzielenia ostatecznie okazuje się dla autora pewną formą arystotelesowskiej przyjaźni dla korzyści (who shares wins). Minimalizm zaś doczekał się już rozlicznych naukowych i popularnonaukowych opracowań, a nawet wysokobudżetowych, pełnometrażowych produkcji filmowych. Przyświecająca mu idea ograniczenia konsumpcji sprowadza 
się w zasadzie do ograniczenia liczby gromadzonych przedmiotów. Założeniem utopii racjonowania jest model gospodarki zapewniający optimum dóbr, czyli - można powiedzieć - racjonalny ich podział. Minimaliści na własną rękę zdefiniowali optimum jako minimum, nie unikając przy tym pułapek konsumpcji dóbr luksusowych. Nie można też wykluczyć, że zgodne z duchem minimalizmu uproszczenie życia wynika raczej z chęci wyróżnienia się w społeczeństwie, w którym coraz trudniej to uczynić.

Utopie racjonowania moga występować w kilku wariantach, w zależności od stanowiska, jakie zajmuja poszczególni utopiści względem własności prywatnej. Przykładem typu utopii, która zapewniałaby z jednej strony optimum dóbr, a z drugiej dobra te nie służyłyby tworzeniu społecznych hierarchii, jest komunizm. W komunistycznej utopii konsumpcja nikogo nie wyróżnia, ponieważ system gospodarczy nie produkuje dóbr pozycyjnych. Można chyba zaryzykować twierdzenie, że każda utopijna idea społeczeństwa prezentowana w tej książce jest mniej lub bardziej komunistyczna, jeśli ostatecznie od braku dystynkcji zależy stabilność porządku społecznego. Najprościej mówiąc, rzeczy, które łączą, należą do kategorii przedmiotów poręcznych, a nie dóbr statusowych czy symbolicznych. W przeciwieństwie do założeń, na jakich ufundowane jest współczesne państwo bezpieczeństwa socjalnego, w utopiach racjonowania chodzi nie o ochronę ludzi przed ubóstwem, lecz przed destrukcyjnym dla tkanki społecznej nadmiarem. Przypomina to oczywiście, mutatis mutandis, polemikę Marksa z socjalizmem utopijnym, w której ostatecznie stawką nie jest świadomość nędzy, lecz odczłowieczenia. Państwo bezpieczeństwa socjalnego nie ma oczywiście wpływu na to, w jaki sposób wolnorynkowe tryby systemu kapitalistycznego ustawicznie generuja nowe potrzeby, dlatego zapewnia jedynie ochronę przed ubóstwem. Utopie racjonowania natomiast reglamentują same potrzeby, a przynajmniej mają zapobiegać ich zbędnemu mnożeniu. Zarówno powszechny dostatek, jak i celowe ubóstwo z wyboru wyrastaja, jak się zdaje, z myślenia utopijnego. Pierwsze - z protokapitalistycznego założenia wysokiej produktywności, drugie z równie kontrfaktycznej idei ograniczenia potrzeb i doświadczeń do tych najbardziej elementarnych.

Wydaje się, że przywołana przez autora mądrość starożytnych jest nie do przecenienia, zwłaszcza w dzisiejszych czasach, gdy łatwiej jest umrzeć, niż znaleźć chwilę wytchnienia dla refleksji nad zwornikami ostatecznymi życia. To właśnie Arystoteles dogłębnie przemyślał i uświadomił nieprzekonanym, że życie ostatecznie składa się z czasu i aby go sensownie przeżyć, zwyczajnie należy nim dysponować. Natarczywa i wszechpochłaniają- 
ca codzienność pozbawia nas czasu, odzierając z niezbędnych do harmonijnego życia chwil skupienia. Współczesny człowiek, jak ujął to niegdyś Nietzsche, kontempluje z nieczystym sumieniem, a poświęcając swój czas na pracę zarobkowa, służącą w coraz większej mierze nabywaniu rzeczy, o których pisze w swej książce Waśkiewicz, samoistnie pozbawia się wolności, stając się w istocie uwspółcześnioną wersją antycznego niewolnika.

Jeśli miałbym wskazać na wspólny mianownik utopijnych wizji porządków społecznych, o których jest mowa w tej książce, zwróciłbym właśnie uwagę na nieubłaganą logikę owego mechanizmu samokolonizacji człowieka. Aby wyobrazić sobie skalę oraz intensyfikację tego osaczenia przez świat przedmiotów materialnych, wystarczy zestawić ze sobą postać starego człowieka ze znanej noweli Hemingwaya i współczesnego Amerykanina. Sam Waśkiewicz w części Żyçliwa wymiana odwołuje się zreszta również do Arystotelesa, zwracając uwagę, że dla Greków to nie poziom kultury materialnej pozwalał odróżniać cywilizację od barbarzyństwa, lecz swoista polityczna forma organizacji życia społecznego, do której potrzebny był wolny czas. Gdyby można wprowadzić czas do wymiany rynkowej na takiej samej zasadzie jak inne dobra, byłby on z pewnością najlepszym nabytkiem, w który warto zainwestować posiadany kapitał. Problemem jest naturalnie również to, w co obfituje cała demonologia Marksa, znana pod nazwą materializmu dialektycznego czy drobiazgowych opisów zjawisk fetyszyzmu towarowego oraz natury wyzysku. Dylemat pozostaje niezmiennie ten sam i dotyczy pogodzenia dwóch asymetrycznych porządków: czasowego, który odnosimy do procesu życiowego, oraz rzeczowego, związanego z procesami utowarowienia, czy mówiąc wprost - sprzedawania swego czasu.

Nie ma najmniejszych wątpliwości, że praca wykonywana jedynie w celu zapewnienia sobie środków do życia nie miała dla Arystotelesa żadnej społecznej wartości. W nieco przerysowany sposób można by powiedzieć, że komercjalizacja naszej uwagi w rzeczywistości późnego kapitalizmu osiągnęła taki poziom, że sen stanowi jedyną przestrzeń prawdziwie ludzkiej wolności, czas wydarty z sideł nieustannej produktywności, efektywności i konsumpcji, na co - nawiasem mówiąc - zwraca uwagę Jonathan Crary w interesującej książce 24/7. Późny kapitalizm i koniec snu (2015). Sen, póki co, wydaje się jedyną sferą całkowicie nieproduktywną, sub specie logiki sytemu kapitalistycznego. Imperatywy wysokiej produktywności współczesnego kapitalizmu są oczywiście zachętą do snucia fantazji o prostym, rzekomo autentycznym życiu w odosobnionej przestrzeni, takiej jak choćby kontr- 
kulturowe komuny lat 60., funkcjonujące przecież w otoczeniu opływającego w standardowe dostatki społeczeństwa konsumpcyjnego.

Książkę Andrzeja Waśkiewicza można polecić tym, którzy chcieliby zarówno nabyć rozeznania w rozmaitości materialistycznych utopii, jak i krytycznie przyjrzeć się fundamentom współczesnego systemu kapitalistycznego, w ramach którego obieg przedmiotów materialnych odgrywa kluczową rolę. Czytelnik znajdzie więc tutaj świetnie uporządkowany materiał i rzetelne rekonstrukcje utopijnych traktatów, o których być może miał dotychczas jedynie mgliste pojęcie. Największy walor tej publikacji leży jednak, moim zdaniem, w sproblematyzowaniu niektórych istotnych dla przemian współczesnego kapitalizmu kwestii, takich jak choćby bezprecedensowa dominacja polityki ekonomicznej, opartej na imperatywie stałego wzbogacania się oraz mnożenia dóbr, polityki prowadzącej do niebywałej polaryzacji dochodów i lawinowego wzrostu nierówności społecznych. Naiwnością byłoby sądzić, że otrzymamy tutaj gotowe odpowiedzi lub recepty, podobnie jak niedorzeczne jest przypuszczenie, że studia filozoficzne pozwolą nam odkryć zagadkę życia i świata. Nie oczekujemy przecież od egzegety utopii projektowania własnych.

Autor przywołuje ponadto niezmiernie interesująca, choć zapomniana już dzisiaj, koncepcję kooperatyw Edwarda Abramowskiego, która z racji społeczno-historycznego kontekstu była w większym stopniu utopią odrodzonej Polski niż przemyślanym sposobem organizacji bezpośredniej wymiany, z pominięciem znaczących ogniw złożonego systemu transakcji wolnorynkowych. Zarówno idea kooperatyw, jak i jej realne wcielenia przeżywają ostatnio prawdziwy renesans, bezkolizyjnie wpisując się w założenia społeczeństwa postwzrostu. Warto w tym miejscu zwrócić uwagę, że za poprawę efektywności gospodarczej miała w kooperatywach odpowiadać eliminacja pośredników, ale przy efekcie skali nowoczesnej gospodarki kapitalistycznej założenia te wydają się nieco anachroniczne. Produkcja wielkoprzemysłowa zapewnia bowiem, jak się okazuje, wymaganą konkurencyjność, a kooperatywy moga obecnie konkurować jedynie jakością produktów, nie ich ceną, nawet przy braku jakichkolwiek pośredników. Utopia Abramowskiego jest jednak bardziej uniwersalna, jeśli uznać, że jej cel był również antropologiczny, a jej autorowi chodziło o rodzaj metanoi, czyli przemianę człowieka.

Sposób myślenia Abramowskiego podziela współcześnie wielu adherentów ekonomii współdzielenia, choć - jak możemy to wywnioskować z samego pojęcia - nie są oni otwarcie wrodzy wobec systemu kapitalistycznego. Są to idee w większym stopniu reformistyczne niż rewolucyj- 
ne. Oczywiście Waśkiewicz proponuje nam czysto deskryptywną analizę. Znajdziemy tutaj takie elementy, jak: powrót do niezapośredniczonych relacji pomiędzy konsumentami, wyeliminowanie wartości statusowych z obrotu dóbr, akcentowanie roli autentycznych potrzeb, troska konsumentów o środowisko naturalne (na przykład żero waste) czy idea kolektywnego korzystania z przedmiotów (jak chociażby car sharing). Taki typ gospodarki z pewnością obiektywnie minimalizuje koszty transakcyjne, ponieważ nie wymaga rozbudowanej i kosztownej infrastruktury zaufania, jaka na poziomie państw pełnią na przykład agencje ratingowe. Oddolnie budowanie zaufanie, tradycyjnie odpowiadające za generowanie kapitału społecznego, okazuje się po prostu najtańszą rynkową opcja (na takiej zasadzie funkcjonował niegdyś w Polsce znany serwis Allegro).

Idea gospodarki służącej realizacji autentycznych potrzeb konsumentów, a nie zyskom producentów jest chyba największą utopią kapitalizmu. Wydaje się, że podobnie jest z kwestionowaniem własności, rozumianej jako posiadanie na wyłączność. Choć posiadanie rzeczy oddala nas od innych, buduje statusowe zapory, wreszcie sprzyja społecznej ekskluzji, utrudniając tworzenie wspólnoty, to jednak „niewyjaśnioną” zagadką pozostaje, dlaczego każdy pragnie mieć własny samochód na podjeździe czy też kosić trawę własną kosiarką. Czy zatem ekonomia współdzielenia uratuje kapitalizm? - zapytuje raczej retorycznie Waśkiewicz. Nie jest jednak jasne, przed czym konkretnie miałaby go ratować, zakładając oczywiście, że kapitalizm znalazł się w opałach, co jest według mnie tezą wątpliwą.

Chciałbym też wspomnieć, że podczas lektury niejednokrotnie miałem trudności z oddzieleniem tego, co jest odautorskim komentarzem, a co rekonstrukcją poglądów twórców prezentowanych utopii. W konsekwencji nie za bardzo wiadomo, w co autor wierzy czy które argumenty wydaja mu się dobrze uzasadnione, a które naiwne, którym koncepcjom sprzyja, a które gotów jest uznać za fantasmagorie. Dotyczy to zwłaszcza utopii wymierzonych w system kapitalistyczny. Dzisiaj natomiast nie ma już większych wątpliwości co do zasadności niektórych argumentów czy utopijnych wizji. Wiemy, co można, czy lepiej-co warto, przemyśleć przy potencjalnej restrukturyzacji systemu kapitalistycznego. Rozumiem oczywiście, że jest to książka historyka idei, a nie wizjonera, ale dla niektórych nieco rozczarowujący może być brak jakiegokolwiek krytycyzmu wobec prezentowanych utopijnych pomysłów.

Bardzo interesujące wydaje mi się za to przywołanie wydanych pod koniec ubiegłego wieku książek dwóch utopistów: Edwarda Bellamy’ego i jego W roku 2000 oraz Wieści z nikeqd: powieś́ utopijna Williama Morrisa. 
Waśkiewicz osadza swoje rozważania w szerszym historycznym kontekście, przypominając o istnieniu prac, które mało kto dzisiaj czyta. Obydwaj wymienieni autorzy, przekonani socjaliści, czerpią inspirację z niektórych wątków marksowskiej krytyki, ale przede wszystkim umieszczaja swoje wizje w historii, nadając im status proroctw par excellence. Zwłaszcza postkapitalistyczna utopia Morrisa stara się rozwiązać podstawowy marksowski problem alienacji pracy. Niewyalienowana praca oznacza, jak wiadomo, skok do królestwa wolności. Rozróżnienie na pracę wyobcowaną i niewyobcowana zostało po raz pierwszy rozwinięte przez Marksa w jego znanych rękopisach ekonomiczno-filozoficznych z 1844 roku. Tam też sformułował on ogólne pojęcie alienacji, w dużym stopniu inspirując się Heglem. Wyalienowana praca polega na tym, że wyobcowuje robotnika, odbierając mu jego narzędzia, produkt jego pracy, sam proces pracy oraz człowieczeństwo. Czy można zatem czytać Morrisa, nie znając Bellamy'ego, albo na odwrót? Każdy tekst utopijny zawiera w sobie całą tradycję gatunku i jeśli zgadzamy się z tezą Jamesona (2011: 2), trudno w inny sposób wyobrazić sobie całe przedsięwzięcie Waśkiewicza. Utopia jest też jednak zdecydowanie czymś więcej niż sumą osobnych tekstów. Impuls utopijny kieruje wszak wszystkimi działaniami, które zwrócone są w przyszłość, jak wyraził to niegdyś Ernst Bloch.

Społeczeństwo krańcowych kosztón zerowych Jeremy'ego Rifkina, całkiem współczesna przywołana przez Waśkiewicza książkę, można z powodzeniem zaliczyć do utopii, ale również, jak się zdaje, do grupy innych publikacji, próbujących uchwycić niejako in statu nascendi rodzaj paradygmatycznej zmiany społecznej, dokonującej się na naszych oczach. Do tego typu prac można zaliczyć popularną w latach 80. Trzecia fale Alvina Tofflera czy Punkt zwrotny Fritjofa Capry, podważający prawomocność mechanistycznego sposobu porządkowania i poznawania rzeczywistości. Swym rozmachem wizja Rifkina zdecydowanie przekracza horyzont nauk społecznych, a jego optymizm, dodać trzeba - nie zawsze uzasadniony, pozwala na zestawienie go w jednym szeregu z autorami prorokującymi fundamentalną zmianę dotychczasowego porządku społecznego. W przeciwieństwie do wymienionych autorów Rifkin skupia się jednak przede wszystkim na aspekcie ekonomicznym i ogólniej - funkcjonowaniu nowej gospodarki, która jest dla niego pewnym wariantem, znanej z poprzednich części książki, ekonomii współdzielenia oraz wizji wspólnoty prosumentów.

Wydaje się, że istnieje co najmniej jeden dobry powód niepozwalający zaliczyć wizji Rifkina, mimo wyrażanego bezustannie entuzjazmu, do grupy innych zwolenników optymistycznej i postępowej wizji społeczeństwa, 
jaką reprezentuje choćby Steven Pinker (2018), zaliczany do apologetów tak zwanego nowego optymizmu. W utopii Rifinka nie ma mianowicie mowy, poza ogólnikami, o sposobach radzenia sobie z narastającym poziomem entropii, jaka generuje każdy ład społeczny, zgodnie z drugim prawem termodynamiki. To zresztą sprawia, że jego książki, jak ujmuje to sam Waśkiewicz, są tekstami utopijnymi, a nie podpartymi empirią pracami analityka rzeczywistości społecznej, które dostarczałyby potencjalnie dostępnych narzędzi rozwiązywania problemów, wynikających z powiększania entropii jako nieuchronnej konsekwencji nowego ładu społecznego. Znacznie większą wstrzemięźliwość i krytycyzm wykazują tutaj tacy autorzy, jak Jason Hickel, autor książek Mniej znaczy lepiej czy The Divide. A Brief Guide to Global Inequality and its Solutions, stawiający wyraźną granicę między optymistyczna progresistowską narracją a nieuzasadnionym, jego zdaniem, entuzjazmem propagatorów nowego optymizmu w rodzaju Pinkera.

Można jedynie podejrzewać, że wizja Rifkina w ogóle nie zasługuje w tym miejscu na krytykę lub polemikę, ponieważ jest właśnie czystą utopia. Jedno jest pewne - gospodarka zerowych kosztów krańcowych ma raz na zawsze rozwiązać odwieczny problem społecznych nierówności, tyle że tym razem w skali globu. Co ciekawe, przekonanie, że to postęp techniczny w wielu dziedzinach życia społecznego odpowiada za stale rosnący dobrobyt, jest argumentem zarówno dla rzeczników nowego humanizmu, wierzących bez zastrzeżeń w racjonalność, naukę i technikę, jak Pinker, jak i dla utopistów w rodzaju Rifkina. O ile ten pierwszy przytacza dziesiątki danych empirycznych, mających uzasadniać jego nieposkromiony optymizm, o tyle drugi roztacza wizje autarkicznej gospodarki oraz wspólnoty szczęśliwych prosumentów, realizujących swoje potrzeby (kaprysy) na drukarkach 3D. Filarem trzeciej rewolucji przemysłowej będzie zatem upadek monopolów i w konsekwencji decentralizacja produkcji, które już w latach 70. zostały nazwane przez E.F. Schumachera (2013) technologią z ludzką twarza, dając podwaliny „ekonomii z założeniem, że człowiek się liczy”.

Kapitalizm po utracie umocowania w religii stał się, jak lapidarnie określa to Waśkiewicz, „bezideowym mechanizmem mnożenia dóbr”. W utopiach obfitości problemem nie jest już sprawiedliwy podział dóbr, lecz wypracowanie odpowiedniej filozofii czasu wolnego. Jest to zagadnienie, którego nie przemyślał Marks, sprowadzające się do pytania, co ludzie będa robić po rewolucji. Całkiem współcześnie w sukurs przychodzą tutaj oczywiście rozmaite strategie samorealizacji, bycia proaktywnym, poszukiwania sensu życia czy podróży w głąb siebie, zwykle karykaturalne i zasilające śmietnik popkultury wariacje na tematy, które opisał już Arystoteles 
w Etyce Nikomachejskiej. Czas wolny, o którym tak wiele pisał Theodor W. Adorno, a który w utopijnych projektach zwykle miał służyć szlachetnym zajęciom intelektualnym, został zawłaszczony przez przemysł kulturalny (2019: 257-267) (w tym wypadku rozrywkowy) i opatrzony etykietą wypoczynku czy urlopu w celu „naładowania baterii”.

Wszystkie utopie sa, co Waśkiewicz w zrozumiały sposób pomija w swej książce, z gruntu klasowe, począwszy od kanonicznej utopii Morusa, pisanej z perspektywy prawnika, humanisty i londyńczyka, utrzymującego zażyłe kontakty z dworem Henryka VIII. Na tej samej zasadzie u Fouriera dostrzeżemy punkt widzenia komiwojażera, elementy kultury kościelnej u Campanelli, a u Bellamy'ego mentalność amerykańskiego drobnomieszczanina przemysłowej epoki wielkich wynalazków. Perspektywę taką przyjmuje w swym studium poświęconym utopiom Fredrick Jameson i jest ona całkowicie odmienna od przyjętej w recenzowanej książce perspektywy historyka idei. W analizie utopii nie można, zdaniem Jamesona, uciec od „pola siłowego ideologii i sytuacyjności klasowej” (2011: 205-209). Waśkiewicz jednak od niego ucieka i czyni to, według mnie, z powodzeniem. Ponadto z ekonomicznych kontekstów produkcji, konsumpcji i dystrybucji Jameson, całkowicie inaczej niż Waśkiewicz, izoluje semiotyczne opozycje, charakterystyczne dla projektów utopijnych. I tak zarówno wizja powrotu do prostoty, jak i estetyczne formy redukcji złożoności są dla niego niepoprawnie nostalgiczne. Pośród tych wizji odnajdziemy regresywne obrazy prostego życia i wiejskiej kultury, właściwe dla lat 60., a także nieco nowsze i równie nieprzekonujące koncepcje wspólnot plemiennych, zjednoczonych przeciwko nieuchronnym następstwom katastrofy ekologicznej i globalnego ocieplenia (Jameson 2011: 193-195).

Czy w socjologicznej lub antropologicznej analizie wymiany darów, o której tak ciekawie pisze Andrzej Waśkiewicz, zwracamy jeszcze uwagę na same przedmioty? Zapewne nieliczni pamiętają o naramiennikach i naszyjnikach krążących w opisanym przez Malinowskiego wewnątrzpacyficznym obiegu kula. Choć trudno o lepszy przykład mechanizmu ukierunkowanego wprost na przedmioty materialne niż wymiana darów, to jednak sam dar w postaci przedmiotu traktowany był zwykle jako epifenomen bardziej złożonych stosunków społecznych lub - w najlepszym wypadku - tak zwana funkcja ukryta w znaczeniu, jakie nadał temu pojęciu Robert Merton. Zarazem jednak świat rzeczy bez interwencji człowieka, poza zasięgiem jego aparatu poznawczego i percepcyjnego, jest pozbawiony znaczenia. Porządek materialny uzyskuje znaczenie dzięki naszemu intencjonalnemu odniesieniu. 
Warto w tym miejscu zwrócić uwagę na ten aspekt książki Waśkiewicza, co być może przekona jeszcze nieprzekonanych do jej lektury. Materialność, czyli porządki rzeczy, o których pisze autor, traktuje się zwykle jako „ślady” czy też „pozostałości” procesów społecznych i historycznych, które same w sobie są niematerialne. W tym sensie cała problematyka tej książki wpisuje się w paradygmatyczny „zwrot ku rzeczom”, które nie są tylko epifenomenami procesów i zjawisk społeczno-kulturowych o niematerialnym charakterze (Olsen 2013). Wydaje się, że rzeczy, ich obieg i wymiana sa dla autora autonomicznym przedmiotem, wartym refleksji. W każdym razie nie traktuje on „porządków rzeczy” jako tekstów, symboli czy narracji. Nie znalazłem w analizowanej publikacji takich określeń, jak „czytanie kultury materialnej” czy „,kultura materialna jako narracja”, które sugerują, że rzeczy nie są tym, czym sądzimy, że są. Często służą one interpretacji pozamaterialnych procesów kultury, tak jak maska plemienia Bambara staje się u Jamesa Clifforda rodzajem metonimicznej reprezentacji całej kultury plemiennej (2000: 233-271). Materialność stanowi więc środek, za pomocą którego badacze próbują dotrzeć do czegoś istotniejszego, co skrywa się za materialnym porządkiem rzeczy.

Od XIX wieku masowa produkcja i konsumpcja, a co za tym idzie cykle wymiany materialnej, nabrały zawrotnego tempa i coraz więcej rzeczy uznajemy po prostu za zbędne. To, co przestarzałe, choć sprawne, jest bardzo często utylizowane, czyli wycofywane z obiegu gospodarczego, a zatem inaczej mówiąc - marnowane. Pisząc o zjawisku współczesnej konsumpcji, z reguły nie dostrzega się tych równoległych procesów niszczenia. Sądzę, że materialistyczne utopie przywracaja po części ten wymiar refleksji, przypominając o mrocznej stronie umasowionej i zestandaryzowanej konsumpcji.

Jeszcze bardziej oczywistym wnioskiem, jaki możemy wyciagnnąć z lektury książki Waśkiewicza, jest przekonanie, że to nie dobrobyt stoi na drodze do ludzkiej emancypacji, lecz nadmierne przywiązanie do bogactwa. Współczesna ekonomia wylansowała PKB na uniwersalny probierz dobrobytu i postępu społecznego, zapominając przy tym, że wzrost gospodarczy często oznacza równoczesny wzrost kosztów społecznych. Z perspektywy czysto ekonomicznej jest więc korzystne, by ludzie się rozwodzili, zapewniając przy tym pracę całej armii prawników, czy też żywili w restauracjach, a nie biesiadowali przy domowym stole, dając utrzymanie rzeszom pracowników branży gastronomicznej. Wszystko to sprzyja oczywiście wzrostowi gospodarczemu, zorganizowanemu wedle zasad współczesnej ekonomii, sprawiając, że wskaźniki liczbowe PKB szybują w górę. Koszty 
społeczne, pozostając jedynie przy tych dwóch różnych przykładach, widoczne sa gołym okiem i streścić można je jednym słowem: atomizacja. Optymalizacja konsumpcji, do której sprowadzić można większość prezentowanych w książce utopijnych projektów, stoi w sprzeczności z modelem wypracowanym w naszej kulturze, ponieważ zachodnia ekonomia zmierza $\mathrm{w}$ istocie do czegoś przeciwnego - do maksymalizacji konsumpcji dzięki optymalnemu modelowi produkcji. Te same statystyki można zatem interpretować jako wskaźnik wzrostu gospodarczego lub ilustrację negatywnych konsekwencji określonego modelu konsumpcji.

Ludzie maja jednak tendencję do poszukiwania ostatecznych rozwiązań w dużej skali, tak jakby życie mogło mieć jakieś ostateczne rozwiązanie, inne niż śmierć. Pytanie o skalę jest niesłychanie istotne zarówno w kwestiach politycznych, społecznych, jak i ekonomicznych. Tajemnica poliszynela pozostaje jednak to, dlaczego budujemy ogromne domy, gdzie większość przestrzeni pozostaje całkowicie niewykorzystana, domostwa, w których zamieszkiwać ma nasze ego, a nie zoptymalizowaną i komfortową przestrzeń do życia codziennego. Ostatecznie ekonomia, której John M. Keynes wróżył los pomniejszej specjalności, jak na przykład stomatologia, stała się najważniejszą nauką na świecie, co znajduje odzwierciedlenie w wadze, jaką współczesne państwa nadaja polityce ekonomicznej. Paradoksalnie można powiedzieć, że im bogatsze państwo, tym trudniej zrobić coś doraźnie nieopłacalnego ekonomicznie, ale wartościowego społecznie. Ekonomia automatyzacji i wielkiej skali jest, zdaniem Schumachera, pozostałościa po dziewiętnastowiecznych stosunkach społecznych i ówczesnym sposobie myślenia, w żaden sposób nie korespondując z wyzwaniami współczesności, które jego zdaniem można sprowadzić do sformułowania Gandhiego: „produkcja przez masy, a nie produkcja masowa”. Dzisiejsza makroekonomia operująca na abstrakcyjnym poziomie zestandaryzowanych i globalnych wskaźników, abstrahująca od jednostki, pozostanie całkowicie bezużyteczna, jeśli nie wejdzie w kontakt z realiami ludzkiej nędzy, frustracji, rozpaczy, alienacji, eskapizmu, stresów czy przeludnienia (Schumacher 2013: 75). W związku z tym materialistyczny model życia oparty na nieustannej i nieograniczonej ekspansji w skończonym środowisku skazany jest na porażkę, co może stanowić lapidarne podsumowanie całej tradycji utopijnego myślenia o porządkach społecznych, w których rzeczy łączą, a nie dziela.

Nadmierne zaangażowanie w rywalizacyjną konsumpcję skutkuje oczywiście nieustanną i stale narastająca cyrkulacją przedmiotów materialnych, która niejako w odwecie za ludzką zachłanność czyni zmaterializowana 
rzeczywistość nieznośnie obojętną w obliczu ziemskich starań. Wiecznie niezaspokojone pożądanie przedmiotów obraca się w iluzję zagarniania atrakcyjnych łupów. Być może to właśnie w utopijnych projektach, tak wnikliwe analizowanych na kartach recenzowanej książki, należy poszukiwać źródeł porażki w oswajaniu świata poprzez nawiązywanie z rzeczami zażyłych relacji, rezerwowanych dotąd jedynie dla związków międzyludzkich. Bo czyż utopie te nie wyrażają tęsknoty za porzuconą nieprzewidywalnościa rzeczy, za utraconym nieodwracalnie rajem bezpośredniości, za którym tęsknimy od co najmniej kilku stuleci?

Nie można wykluczyć, że potrzeba posiadania rzeczy na własność wynika $z$ głębszej potrzeby humanizowania nieprzewidywalnej i obojętnej na zmagania człowieka rzeczywistości. Iluzoryczność quasi-intymnego związku, pod którym pulsuje bezosobowa obojętność materialności, wydaje się obracać przeciwko tym, którzy zbyt dosłownie pojęli potrzebę otaczania się ziemskimi posiadłościami. Nie chodzi w tym miejscu o płytką i naiwna moralistykę, opierająca się na zdystansowanej pogardzie dla komfortu codziennego życia, zapewnianego przez rzeczy materialne. Problem dotyczy wspomnianych już mechanizmów samokolonizacji, które za sprawą rzeczy mogą w skrajnym przypadku wydziedziczać z ludzkiej wspólnoty. Kiedy przestajemy traktować rzeczy zgodnie z zasada poręczności, nieuchronnie próbujemy nadać naszemu do nich stosunkowi charakter zażyłości, co całkiem współcześnie obrazuje stosunek niektórych mężczyzn do posiadanych przez nich samochodów. Ujmując to bardziej dosłownie, można by powiedzieć, że nolens volens przenosimy rzeczy w pole osobowego istnienia, mającego maskować ich materialną postać. Nietrudno jednak zauważyć, że jest to zadanie niewykonalne, przysparzające ostatecznie nieszczęsnym posiadaczom kolejnych trosk i zmartwień. Czyż w takiej sytuacji utopie, o których mowa w recenzowanej tu książce, nie są jedyną alternatywą skomercjalizowanego kapitalizmu?

Bibliografia:

/// Adorno T.W. 2019. Czas wolny, [w:] Przemyst kulturalny. Wybrane eseje o kulturze masowej, thum. M. Bucholc, NCK, s. 257-267.

/// Clifford J. 2000. O kolekcjonowaniu kultury i sztuki, [w:] tegoż, Kłopoty z. kultura, tłum. E. Dżurak, Wydawnictwo KR, s. 233-271. 
/// Crary J. 2015. 24/7. Późny kapitaliźm i koniec snu, tłum. D. Żukowski, Karakter.

/// Jameson F. 2011. Archeologie prayszłości. Pragnienie zwane utopia i inne fantazje naukowe, tłum. M. Płaza, M. Frankiewicz, A. Miszk, Wydawnictwo UJ.

/// Olsen B. 2013. W obronie rzeczy. Archeologia i ontologia przedmiotów, tlum. B. Schallcross, Instytut Badań Literackich PAN.

/// Pinker S. 2018. Nowe Oświecenie. Argumenty za rozumem, nauka, bumanizmem i postepem, tłum. T. Bieroń, Zysk i s-ka.

/// Schumacher E.F. 2013. Małe jest piekene. Ekonomia z zatożeniem, że człowiek się liczy, tłum. E. Szymańska-Wierzyńska, J. Strzelecki, Aletheia.

/// Tomasz Maślanka - socjolog i filozof, pracuje na Wydziale Socjologii Uniwersytetu Warszawskiego. Zajmuje się współczesnymi teoriami kultury, socjologia i filozofią kultury, teorią społeczna, intelektualną historia Europy oraz historią idei. Autor oraz współredaktor kilku książek oraz kilkudziesięciu artykułów naukowych. Publikował między innymi w „Polish Sociological Review”, „Colloquia Communia”, „Państwie i Społeczeństwie”, „Stanie Rzeczy”, „Politeji” oraz „Sage Studies in International Sociology". Jego ostatnia książka jest poświęcona fenomenowi kontrkultury (Kontrkultura. Źródła i konsekwencje radykalizmu spoteczno - kulturowego w perspektywie socjologii kultury, 2017).

ORCID: https://orcid.org/0000-0001-7498-2324

E-mail: maslankat@is.uw.edu.pl 